\title{
ACADEMIC CONTRIBUTIONS IN ENTREPRENEURSHIP TOURISM RESEARCH. A BIBLIOMETRIC ANALYSIS
}

\author{
Carmen Florina Fagadar, Diana Teodora Trip, Daniel Badulescu ${ }^{\star}$ \\ Department of Economics and Business \& Doctoral School of Economics, Faculty of \\ Economic Sciences, University of Oradea, Oradea, Romania \\ carmen.fagadar@emanuel.ro \\ dianateodora.trip@gmail.com \\ dbadulescu@uoradea.ro
}

\begin{abstract}
Tourism is one of the largest global industries; it generates economic and non-economic benefits for the world's nations, creates opportunities for many related industries, and has a significant contribution to local communities' prosperity. Despite the extraordinary difficulties posed by the global pandemic crisis, its prospects to remain one of the main providers of jobs, income, and regional or global development are still encouraging. However, tourism is at a crossroads, and the contribution of entrepreneurship can give a new meaning, a new direction to the efforts to recover and resume growth. That is why it is important to understand the nature, scope, challenges, and dimensions of tourism entrepreneurship, the trends that accompanied its evolution in recent decades, and to perceive its future prospects. The emergence of new types and forms of tourism, the expansion of digital technology in most tourism sectors, challenges in existing practices, competition, and the changing models have to be carefully understood and analysed. Tourism and entrepreneurship, two driving forces for economic development, have been under the scrutiny of this study, as we tried to map out the knowledge base yielded between 1994 and 2020 timeframe. Bibliometric methods were employed in the analysis of articles. After analysing the available articles chosen with the criteria set of the study, 322 articles concerning tourism and entrepreneurship were obtained. Based on the citation analysis made with HistCite software, we identified the most influential authors, articles, and journals.
\end{abstract}

Keywords: tourism; entrepreneurship; research topics; bibliometric analysis.

JEL classification: L83; Z32; L26; C88.

\section{Introduction}

Tourism is one of the largest global industries; the 2019 data report over 1.5 billion international tourist arrivals (overnight visitors), revenues of approximately 2.9 trillion US dollars, and $10 \%$ of world jobs (The World Tourism Organization (UNWTO), 2019).

However, in 2020, tourism was one of the sectors most affected by the coronavirus pandemic; international tourism collapsed by about $80 \%$, and destinations that relied heavily on international tourism, business, and events faced particular difficulties (OECD, 2020). According to the OECD, restoring tourism in the coming years is a priority, but the sector

\footnotetext{
*Corresponding author: Daniel Badulescu

Cite as:

Fagadar, C.F., Trip, D.T., and Badulescu D., 2021. Academic Contributions in

Entrepreneurship Tourism Research. A bibliometric analysis. Oradea Journal of

Business and Economics, 6(1), pp. 62-73. http://doi.org/10.47535/19910jbe122
} 
needs to become more sustainable and resilient in the future. Domestic tourism has restarted and has begun to mitigate the impact on jobs and businesses in certain destinations. Still, the recovery will only be real when international tourism approaches the 2017-2019 figures.

In order for tourism development strategies to be able to transform a country's natural and human resources into an economic capital so necessary for development (UNWTO, 2013), they must also take into account the extraordinary potential of entrepreneurship, the dynamism of the small and medium enterprise sector. Moreover, small and medium enterprises in this sector play an increasingly important role in growing turnover, supplying quality services, generating jobs, revitalizing related branches of the economy, promoting new destinations and forms of tourism (Hallak, et al., 2012), encouraging the local community to get involved in tourism activities, with the tourism entrepreneur being the persona causa of tourism development (Koh \& Hatten, 2002).

Because entrepreneurship is an inherent local phenomenon (Baron \& Markman, 2000), (Sternberg, 2012), we can consider that natural resources, cultural heritage, and the potential of local communities can become, through creative and sustainable use, essential components of tourism products and of the tourist experience (Badulescu \& Badulescu, 2012), arguments that demonstrate the interdependence between tourism and entrepreneurship, especially in the context of sustainable development (Kuckertz \& Wagner, 2010), (Crnogaj, et al., 2014), (Badulescu et al, 2014). Starting from the fact that most tourism products are based on cultural and natural heritage, tourism enterprises must find a balance between financial, environmental, and community sustainability (Badulescu, et al., 2020).

In this article, we are interested in investigating the main corpus of literature on tourism entrepreneurship, as described in selected articles published during the last decades, aiming to review entrepreneurial research in the tourism and hospitality industry and provide directions for future research. Specific objectives addressed include examining the research themes and identifying directions of research, as well as identifying the most influential authors, articles, and journals in tourism entrepreneurship research. The paper is organized as follows. In the second section, we present the literature and in the third section, the methodology employed. In the fourth section we discuss the findings, displaying the results in tabular form of the results; in the final section, we conclude and present the main implications and limitations of the study.

\section{Highlights of tourism entrepreneurship literature}

The importance of entrepreneurship in fostering innovation and competitiveness, increasing productivity, and generating employment, wealth, and income for public budgets is widely accepted. Implicitly, it also determines researchers' interest in discovering its forms, causes, apparition, motivators, and ability to exploit opportunities, connections to lifestyle, successes, and failures (Audretsch \& Keilbach, 2004), (Carter, et al., 2003), (Santarelli \& Vivarelli, 2007), (Shane \& Venkataraman, 2000), yielding a literature that is expanding every year. In time, research and analysis methods extended to diverse topics such as local and regional development, cultural influences, relations with local communities and interested participants, social innovation (Audretsch \& Thurik, 2001), (Fischer \& Nijkamp, 2009), (Baron \& Markman, 2000). However, entrepreneurial research on distinct economic sectors and activities yields somewhat contradictory results. Such dissonances between fundamental theories and individual research attempts stem from the differences and specificities of each industry.

Although there is an increasing interest in tourism entrepreneurship, there are rather few studies (meta-researches) on the progress of entrepreneurial research in the industry. We 
should nonetheless mention Li (2008), (Carmichael \& Morrison, 2011), Solvoll et al. (2015), Ratten (2019), Crnogaj, et al. (2014), or Fu et al. (2019). The latter concludes that tourism entrepreneurship is well-represented in practice, but its theoretical aspects are poorly developed (Fu, et al., 2019) being characterized by two main contradictory tendencies: one attempting to integrate tourism entrepreneurship within the general framework of entrepreneurship, and the second considering tourism entrepreneurship to be (intrinsically) different from other types of entrepreneurship, requiring specific theoretical approaches (Solvoll, et al., 2015). Moreover, Li (2008) analysed articles on tourism entrepreneurship published in quality journals between 1986 and 2006 and noticed a certain methodological simplicity in terms of analytical and statistical instruments employed. He also found that, in general terms, tourism entrepreneurship is rather poorly represented, despite the existence of numerous opportunities, topics, and subfields that might be of interest for future studies (Li, 2008). More than ten years after his analysis, we consider some of these gaps to have been solved, but many topics have barely been researched, if at all. Therefore, further review of published papers to build an overview of the field, recognize past trends and prospects of the coming decades, and identify areas for attention and future improvements is all the more necessary.

\section{Research Methodology}

\subsection{General considerations}

In order to chart the knowledge base on tourism and hospitality entrepreneurship for the last decades and test the above-mentioned research trends dawning in the time frame selected for research, a bibliometric analysis was employed. This quantitative, scientometric method has gained a lot of popularity, coupled with the development of specialized research databases (e.g., Web of Science) that make research information readily available (King, 1987).

Bibliometric analysis is recognized as a method for measuring, studying, and monitoring scientific publications and their impact on the scientific community (King, 1987), (De Oliveira, et al., 2019). Among the types of information revealed by such analysis, we mention scientific output data (e.g., number of publications produced by a research unit), scientific impact (e.g., number of citations received by publications), scientific collaboration (data on coauthored publications, national \& international and university-industry collaborations), interdisciplinarity (degree of publications' interdisciplinarity based on the fields cited by the publication).

The research question we address is:

$R Q$. What authors, articles, and journals are the most influential in tourism entrepreneurship research?

De Oliveira et al. (2019) propose a process for the mapping of the knowledge base through bibliometric analysis, a process that also has been undertaken for the study herein. As presented in the Introduction, we propose to study the tourism entrepreneurship state of the art, crisscrossing the two major fields of entrepreneurship and tourism in order to see the research interest captured by this binary field.

\subsection{Defining search platforms, mining, and analyzing bibliometric data}

We have chosen Web of Science as the right platform for this research. WoS is credited with having the most robust databases, the oldest and most comprehensive records of citation indexes, with reasonable availability of search filters, encompassing a useful analysis tool (De Oliveira, et al., 2019), (Ellegaard \& Wallin, 2015). Choosing just one platform for the search is based on two main reasons. Firstly, structural differences between platforms would render the analysis difficult; secondly, although other platforms offer a collection of 
relevant and extensive publications for the research purposes here, the WoS platform represents an established corpus of publications which is more discriminatory in its selective criteria and has the capacity to focus easier on a subject in its database search. The bibliometric data offered by the WoS platform is year of publication, research areas, types of documents, keywords, language, articles, authors, journals, institutions, countries, journal JCR index.

The binary field of study assumed by this research involved the use of the two main terms tourism and entrepreneurship - for the search of all scientific papers studying these two concepts. Thus, the following search profile was established in WoS:

\section{(“entrepreneurship" OR “entrepreneurial” OR "entrepreneur") AND "tourism"}

This search profile, although not exhaustive, yielded a comprehensive number of scientific documents for further study.

The search results have been treated with a series of refinement criteria. Thus, the time frame criterion was completely liberalized, our interest being manifested for the whole period of platform indexation. The results spanned from the years 1995 to 2020 (21st of June, 2020 was the date of the search). The language criterion was limited to the English language, and the document types to articles, i.e., book chapters and proceedings, have been excluded. The categories considered for the search in WoS were hospitality, leisure, sport, tourism, management, business, and economics, the research area being economics.

Following the search and refinement stage, 322 list items were obtained. For each publication, the full record, including cited references, was retrieved. The data is subsequently analyzed with the help of HistCite software, a quantitative method for analyzing systematic literature reviews (Zupic \& Čater, 2015). The main purpose of the software is to make it accessible for researchers and authors to perform bibliometric analysis (Bankar \& Lihitkar, 2019) by identifying the most significant authors, journals, cited reference, institutions, and countries (Thelwall, 2008).

\section{Findings and discussion}

Retrieving the data imported into HistCite, and using the bibliometric parameters extracted from the software, we addressed $R Q$ and pinpointed the most influential articles, authors, and journals pertaining to this study.

\subsection{Yearly Output}

The HistCite results reveal that between 1995 and 2006 there were published only nine research articles. As shown in Figure 1, from 2007 to 2020, 313 papers were published, with 235 of these in the last five years. This finding indicates that tourism entrepreneurship is quite a new field of research and upholds the fact that, before 2006, tourism entrepreneurship was in the evolutionary stages of the concept. The ascending number of annual publications points out that the subject began to represent an area of interest for authors. 


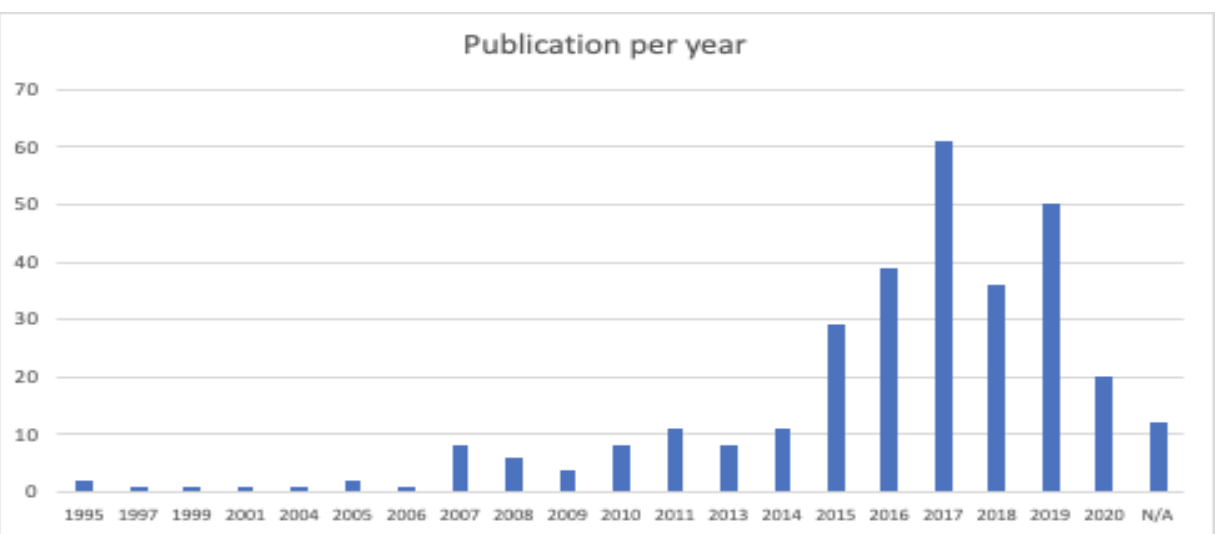

Figure 1: Number of publications on tourism entrepreneurship per year

Source: retrieved from HistCite

\subsection{The most influential authors, articles and journals}

The study revealed that the 322 articles were written by 721 authors. The most productive author in tourism entrepreneurship research is Hallak, with six articles, of which four were written in recent years. The top authors in the tourism entrepreneurship field are presented in Table 1, ranked by the count of publications, and most of the top scorers will appear in all lists presented in the article.

Table 1: Most productive authors from 322 tourism entrepreneurship publications Publications ranking

Source: retrieved from HistCite

\begin{tabular}{|c|l|c|}
\hline No. & Authors & Publications \\
\hline 1 & Hallak, R. & 6 \\
\hline 2 & Lee, C. & 5 \\
\hline 3 & Ratten, V. & 5 \\
\hline 4 & Alonso, A.D. & 4 \\
\hline 5 & Aleawadieh, Z. & 4 \\
\hline 6 & Bakas, F.E. & 4 \\
\hline 7 & Liu, C.H. & 4 \\
\hline 8 & Altinay, L. & 3 \\
\hline 9 & Daniele, R. & 3 \\
\hline 10 & Day, J. & 3 \\
\hline
\end{tabular}

In order to determine the most-influential authors among our collection, we ranked the 721 authors using TLCS (Total Local Citations Score) into a top-10 authors list. The total local citations score (TLCS) indicates how many times the article was cited within the collection of the retrieved set. Here, Haber placed first, with a TLCS of 23, followed by Page, Swan, and Thomas, who had a score of 21, all from one paper entitled Understanding small firms in tourism: A perspective on research trends and challenges (Thomas, et al., 2011) (Table 2). 
Table 2: Most influential authors from 322 tourism entrepreneurship publications TLCS ranking

\begin{tabular}{|c|l|c|c|c|}
\hline No. & Authors & Publications & TLCS & TGCS \\
\hline 1 & Haber S & 3 & 23 & 273 \\
\hline 2 & Page SJ & 1 & 21 & 194 \\
\hline 3 & Shaw G & 1 & 21 & 194 \\
\hline 4 & Thomas R & 1 & 21 & 194 \\
\hline 5 & Hallak R & 6 & 19 & 168 \\
\hline 6 & Lerner M & 1 & 15 & 102 \\
\hline 7 & Li L & 1 & 15 & 76 \\
\hline 8 & Komppula R & 1 & 12 & 133 \\
\hline 9 & Brown G & 1 & 10 & 82 \\
\hline 10 & Lindsay NJ & 1 & 10 & 82 \\
\hline
\end{tabular}

Source: retrieved from HistCite

The next step was to sort the most influential authors according to TGCS (Total Global Citation Score). This bibliometric criterion measures how many times an article was cited globally by other articles, not only in the ones inside the collection. Some top authors of the TLCS list (Haber, Page, Shaw, Thomas, Hallak) are in the TGCS list as well. Their Global Citation Score is much higher than the local ones because citations from outside the collection were taken into consideration. Here (Table 3), Haber ranked first, with a TGCS of 273 citations; Orfila-Sintes, Sorensen, and Sundbo each had 223. Orfila-Sintes and Sundbo had the score from the same publication, The innovative behaviour of tourism firms Comparative studies of Denmark and Spain (Sundbo, et al., 2007). It is interesting to observe a highly cited article, Silberberg 's (Silberberg, 1995), with a TGCS of 221, has only a small TLCS (the article has a TLCS of 0 ). We can assume that there is little or no relatedness between this article and our collection. TGCS score can often be high when the article in question has a multidisciplinary impact (Garfield, et al., 2006).

Table 3: Most influential authors from 322 tourism entrepreneurship publications TGCS ranking

Source: retrieved from HistCite

\begin{tabular}{|c|l|c|c|c|}
\hline No. & Authors & Publications & TLCS & TGCS \\
\hline 1 & Haber, S. & 3 & 23 & 273 \\
\hline 2 & Orfila-Sintes, F. & 1 & 10 & 223 \\
\hline 3 & Sorensen, F. & 2 & 10 & 223 \\
\hline 4 & Sundbo, J. & 1 & 10 & 223 \\
\hline 5 & Silberberg, T. & 1 & 0 & 221 \\
\hline 6 & Page, S.J. & 1 & 21 & 194 \\
\hline 7 & Shaw, G. & 1 & 21 & 194 \\
\hline 8 & Thomas, R. & 1 & 21 & 194 \\
\hline 9 & Reichel, A. & 2 & 8 & 171 \\
\hline 10 & Hallak, R. & 6 & 19 & 168 \\
\hline
\end{tabular}

To assess the most influential research papers within our collections, we ranked them using TLCS/t (Total Local Citation Score/Year) and then after TGCS/t (Total Global Citation Score/Year). When studying co-authorship, it's important to see how the total number of articles produced per year evolves because two authors, when acting together, do not produce more than one article. The score per year shows the average citation score since the publication date. 
Hallak attained a TLCS/t of 3.04 (Table 4), with six articles published together with Brown and Lindsay (Hallak, et al., 2012), with Lee and Sardeshmukh (Lee, et al., 2016), (Lee, et al., 2016), (Lee, et al., 2019), with Lee (Lee \& Hallak, 2018), (Lee \& Hallak, 2020). The citation of Hallak's paperwork attracted the attention of the academic community, therefore, it obtained exponential growth, being used as a reference in 63 articles in 2012, 142 articles in 2016, 245 articles in 2018, 284 articles in 2019, and 322 articles in 2020. Alrawadieh has the higher score, TLCS/s 3.33, even with fewer articles, indicating that the author's paperwork has the most yearly cited references score in our collection.

Table 4: Most influential authors from 322 tourism entrepreneurship publications - TLCS/t ranking

\begin{tabular}{|c|l|c|c|}
\hline No. & Authors & Publications & TLCS/t \\
\hline 1 & Alrawadieh, Z. & 4 & 3.33 \\
\hline 2 & Hallak, R. & 6 & 3.04 \\
\hline 3 & Page, S.J. & 1 & 2.10 \\
\hline 4 & Shaw, G. & 1 & 2.10 \\
\hline 5 & Thomas, R. & 1 & 2.10 \\
\hline 6 & Lee, C. & 5 & 1.93 \\
\hline 7 & Sigala, M. & 3 & 1.80 \\
\hline 8 & Kompulla, R. & 1 & 1.71 \\
\hline 9 & Sardeshmukh, S.R. & 3 & 1.60 \\
\hline 10 & Cetin, G. & 1 & 1.50 \\
\hline
\end{tabular}

Source: retrieved from HistCite

In Table 5 we can observe that the citation of Hallak attained the highest TGCS/t (Total Global Citation Score/Year), 28.84. Lee had been cited 19.73 annually, with the authorship of five articles published between 2016-2020 together with Hallak (2 articles) and Hallak and Sardeshmukh (3 articles). Page received an average TGCS/t score of 19.40, and his score was entirely due to his co-author status with Thomas on only one publication. Similarly, Shaw is in fourth place, with a score of $19.40 \mathrm{TGCS} / \mathrm{t}$, also as a co-author on the Thomas paper.

Table 5: Most influential authors from 322 tourism entrepreneurship publications - TGCS/t ranking

\begin{tabular}{|c|l|c|c|}
\hline No. & Authors & Publications & TGCS/t \\
\hline 1 & Hallak, R. & 6 & 28.84 \\
\hline 2 & Lee, C. & 5 & 19.73 \\
\hline 3 & Page, S.J. & 1 & 19.40 \\
\hline 4 & Shaw, G. & 1 & 19.40 \\
\hline 5 & Thomas, R. & 1 & 19.40 \\
\hline 6 & Komppula, R. & 1 & 19.00 \\
\hline 7 & Altinay, L. & 3 & 17.50 \\
\hline 8 & Haber, S. & 3 & 16.89 \\
\hline 9 & Sardeshmukt, S.R. & 3 & 16.40 \\
\hline 10 & Orfila-Sintes, F. & 1 & 15.93 \\
\hline
\end{tabular}

Source: retrieved from HistCite

What are the top journals in the tourism entrepreneurship research domain (local and global)? The studies obtained in the field of tourism and entrepreneurship were found to be published in 141 academic journals. The most significant were indexed using a top 10 
journals list according to TLCS and TGCS. Top 10 most influential journal generated by HistCite according to TLCS:

1. Tourism Management - 41 articles

2. International Journals of Contemporary Hospitality Management - 22 articles

3. Journal of Business Venturing - 2 articles

4. Service Industries Journal - 10 articles

5. Research Policy - 1 article

6. Journal of Hospitality and Tourism Management - 11 articles

7. Entrepreneurship and Regional Development - 6 articles

8. Social Entrepreneurship and Tourism: Philosophy and Practice - 15 articles

9. Forest Policy and Economics - 2 articles

10. International Journal of Entrepreneurial Behavior \& Research - 8 articles

According to TGCS, top 10 influential journals are:

1. Tourism Management - 41 articles

2. Journal of Business Venturing - 2 articles

3. Research Policy - 1 article

4. International Journal of Contemporary Hospitality Management - 22 articles

5. Service Industries Journal - 10 articles

6. Entrepreneurship and Regional Development - 6 articles

7. Journal of Destination Marketing \& Management - 5 articles

8. International Small Business Journal -2 articles

9. Tourism Management Perspectives - 11 articles

10. Journal of Hospitality and Tourism Management - 11 articles

As it can be seen in the above list, the leading journal in both rankings is the same, i.e., Tourism Management. Forty-one articles were published in the first ranking journal Tourism Management, with a TLCS of 110 (the highest score). Seven of these were published before 2007 , and the remainder were published in 2007-2020. Regarding the themes or subject area covered by both top-10 influential journals lists in tourism entrepreneurship, a few clearly dominant ones are tourism, business, management, economics, and sociology.

After listing the most important journals, we wanted to identify the most cited references in the collection. The Publications field shows the number of papers in which the references are cited. As shown in Table 6, 3 of 10 papers were published in Tourism Management Journal, two of which are ranked in the first two places in the most cited references list. 
Table 6: Most cited references from 322 tourism entrepreneurship publications - TGCS/t ranking

\begin{tabular}{|c|c|c|}
\hline No. & Authors/Year/Title/Journal & $\begin{array}{l}\text { Publications that } \\
\text { cited the article }\end{array}$ \\
\hline 1 & $\begin{array}{l}\text { Hjalager, AM. (2010). A review of innovation research } \\
\text { in tourism. Tourism Management }\end{array}$ & 26 \\
\hline 2 & $\begin{array}{l}\text { Getz, D., Carlsen, J. (2000). Characteristics and goals } \\
\text { of family and owner-operated businesses in the rural } \\
\text { tourism and hospitality sector. Tourism Management }\end{array}$ & 24 \\
\hline 3 & $\begin{array}{l}\text { Ateljevic, I. (2000). Staying within the fence: Lifestyle } \\
\text { Entrepreneurship in Tourism. Journal of Sustainable } \\
\text { Tourism }\end{array}$ & 22 \\
\hline 4 & $\begin{array}{l}\text { Lumpkin, G.T., Dess, G. (1996). Clarifying the } \\
\text { entrepreneurial orientations construct and linking it to } \\
\text { performance. The Academy of Management Review }\end{array}$ & 22 \\
\hline 5 & $\begin{array}{l}\text { Eisenhardt, K.M. (1989). Building theories from case } \\
\text { study research. The Academy of Management Review }\end{array}$ & 21 \\
\hline 6 & $\begin{array}{l}\text { Mair, J., Marti, I. (2006). Social entrepreneurship } \\
\text { research: A source of explanation, prediction, and } \\
\text { delight. Journal of World Business }\end{array}$ & 21 \\
\hline 7 & $\begin{array}{l}\text { Shane, S., Venkataraman, S. (2000). The promise of } \\
\text { Entrepreneurship as a Field of Research. Academy of } \\
\text { Management Review }\end{array}$ & 21 \\
\hline 8 & $\begin{array}{l}\text { Thomas, R., Shaw, G., Page, S.J. (2011). } \\
\text { Understanding small firms in tourism: A perspective on } \\
\text { research trends and challenges. Tourism Management }\end{array}$ & 21 \\
\hline 9 & $\begin{array}{l}\text { Barney, J. (1991). Firm Resources and Sustained } \\
\text { Competitive Advantage. Journal of Management }\end{array}$ & 16 \\
\hline 10 & $\begin{array}{l}\text { Getz, D., Carlsen, J. (2004). Family business in } \\
\text { tourism: State of the Art. Annals of Tourism Research }\end{array}$ & 16 \\
\hline
\end{tabular}

Source: retrieved from HistCite

\section{Conclusions, implications, and limitations}

The present study contributes to a deeper understanding of the literature on tourism entrepreneurship by painting the picture of this research field through clear segmentation and systematic grouping of the bibliometric data. Using HistCite, the data was analysed, and the most influential articles, authors, and journals were identified.

With these gaps and trends identified through the bibliometric research, we can acknowledge the points underlined in the literature review as areas either in need of more comprehensive study or as hot spots in future research - even both. The uniqueness of the times lived now, a worldwide pandemic, which has affected in a major way the tourism sector makes this research a welcome map of the tourism entrepreneurship knowledge base and a backdrop for future similar endeavours.

Although the research has particularly focused on finding all published articles in WoS having tourism and entrepreneurship keywords in the title, the keywords, and abstract, there could be other relevant studies of tourism entrepreneurship which did not meet the search criteria. The main limitations come from the selected platform (i.e., Web of Science), research type (i.e., articles), and language of publications (i.e., English). While the scope of 
this research has been clearly delineated, future research can increase the amplitude of the study by adding other scientific works from Scopus and similar platforms.

\section{References}

Audretsch, D. \& Keilbach, M., 2004. Entrepreneurship and regional growth: an evolutionary interpretation. Journal of Evolutionary Economics, 14 (5), pp. 605-616. https://doi.org/10.1007/s00191-004-0228-6.

Audretsch, D. \& Thurik, R., 2001. Linking Entrepreneurship to Growth, OECD Science, Technology and Industry Working Papers, 2001/2, Paris: OECD Publishing. https://doi.org/10.1787/736170038056.

Badulescu, A. \& Badulescu, D., 2012. Entrepreneurship and Local Resources. In: D. Leslie, ed. Tourism Enterprises and the Sustainability Agenda across Europe. UK: Ashgate Publishing, pp. 151-168.

Badulescu, A., Badulescu, D. \& Borma, A., 2014. Enhancing cross-border cooperation through local actors' involvement. The case of tourism cooperation in Bihor (Romania) Hajdú-Bihar (Hungary) Euroregion. Lex Localis - Journal of Local Self-government, 12 (3), pp. 349-371. https://doi.org/10.4335/12.3.349-371(2014).

Badulescu, A., Badulescu, D. \& Stiubea, E., 2020. How Do New Ventures Operating in Tourism Industry Relate to Their Financial Goals? In: V. Katsoni \& T. Spyriadis, ed. Cultural and Tourism Innovation in the Digital Era. Cham, Switzerland: Springer Proceedings in Business and Economic. https://doi.org/10.1007/978-3-030-36342-0 40.

Bankar, R. \& Lihitkar, S., 2019. Science Mapping and Visualization Tools Used for Bibliometric and Scientometric Studies: A Comparative Study. Journal of Advancements in Library Sciences, 6 (1). https://doi.org/10.37591/joals.v6i1.1807.

Baron, R. \& Markman, G., 2000. Beyond social capital: the role of social competence in entrepreneur's success. Academy of Management Executive, 14 (1), pp. 106-116.

Carmichael, B. \& Morrison, A., 2011. Tourism Entrepreneurship Research. Tourism Planning \& Development, $8 \quad$ (2), $\quad$ pp. $115-119$. https://doi.org/10.1080/21568316.2011.573910.

Carter, N., Gartner, W., Shaver, K. \& Gatewood, E., 2003. The career reasons of nascent entrepreneurs. Journal of Business Venturing, 18 (1), pp. 13-39. https://doi.org/10.1016/S0883-9026(02)00078-2.

Crnogaj, K., Rebernik, M., Bradac Hojnik, B. \& Omerzel Gomezelj, D., 2014. Building a model of researching the sustainable entrepreneurship in the tourism sector. Kybernetes, 43 (3/4), pp. 377-393. https://doi.org/10.1108/K-07-2013-0155.

De Oliveira, J. et al., 2019. Bibliometric Method for Mapping the State-of-the-Art and Identifying Research Gaps and Trends in Literature: An Essential Instrument to Support the Development of Scientific Projects. In: S. Kunosic \& E. Zerem, ed. Scientometrics Recent Advances. London, UK: IntechOpen. https://doi.org/10.5772/intechopen.85856.

Ellegaard, O. \& Wallin, J., 2015. The Bibliometric Analysis of Scholarly Production: How Great Is the Impact?. Scientometrics, $105 \quad$ (3), pp. 1809-1831. https://doi.org/10.1007/s11192-015-1645-z.

Fischer, M. \& Nijkamp, P., 2009. Entrepreneurship and Regional Development. In: R. Capello \& P. Nijkamp, ed. Handbook of Regional Growth and Development Theories. Cheltenham, UK: Edward Elgar, pp. 182-198.

Fu, H., Okumus, F., Wu, F. \& Köseoglu, M., 2019. The entrepreneurship research in hospitality and tourism. International Journal of Hospitality Management, 78, pp. 1-12. https://doi.org/10.1016/j.ijhm.2018.10.005.

Garfield, E., Paris, S. \& Stock, W., 2006. HistCite: A software Tool for Infometric Analysis of Citation Linkage. Information, 57 (8), pp. 391-400. 
Hallak, R., Brown, G. \& Lindsay, N., 2012. The place Identity - Performance relationship among tourism entrepreneurs: A structural equation modelling analysis. Tourism Management, 33 (1), pp. 142-154. https://doi.org/10.1016/..tourman.2011.02.013.

King, J., 1987. A Review of Bibliometric and Other Science Indicators and Their Role in Research Evaluation. Journal of Information Science, 13 (5), pp. 261-276. https://doi.org/10.1177/016555158701300501.

Koh, K. \& Hatten, T., 2002. The Tourism Entrepreneur; : The overlooked player in tourism development studies. International Journal of Hospitality \& Tourism Administration, 3 (1), pp. 21-48. https://doi.org/10.1300/J149v03n01 02.

Kuckertz, A. \& Wagner, M., 2010. The influence of sustainability orientation on entrepreneurial intentions - Investigating the role of business experience. Journal of Business Venturing, 25 (5), pp. 524-539. https://doi.org/10.1016/.j.jbusvent.2009.09.001.

Lee, C. \& Hallak, R., 2018. Investigation the moderating role of education on a structural model of restaurant performance using multi-group PLS-SEM analysis. Journal of Business Research, Elsevier, 88 (C), pp. 298-305. https://doi.org/10.1016/i.jbusres.2017.12.004.

Lee, C. \& Hallak, R., 2020. Investigating the effects of offline and online social capital on tourism SME performance: a mixed-methods study of New Zealand entrepreneurs. Tourism Management, 80. https://doi.org/10.1016/j.tourman.2020.104128.

Lee, C., Hallak, R. \& Sardeshmukh, S., 2016. Drivers of success in independent restaurants: A study of the Australian restaurant sector. Journal of Hospitality and Tourism Management, 29, pp. 99-111. https://doi.org/10.1016/i.jhtm.2016.06.003.

Lee, C., Hallak, R. \& Sardeshmukh, S., 2016. Innovation entrepreneurship, and restaurant performance: A higher-order structural model. Tourism Management, 53, pp. 215-228. https://doi.org/10.1016/j.tourman.2015.09.017.

Lee, C., Hallak, R. \& Sardeshmukh, S., 2019. Creativity and innovation in the restaurant sector: Supply-side processes and barriers to implementation. Tourism Management Perspective, 31, pp. 54-62. https://doi.org/10.1016/i.tmp.2019.03.011.

Li, L., 2008. A review of entrepreneurship research published in the hospitality and tourism management journals. Tourism Management, 29 (5), pp. 1013-1022. https://doi.org/10.1016/i.tourman.2008.01.003.

OECD, 2020. Rebuilding tourism for the future: COVID-19 policy responses and recovery. [online].

Available

at:

http://www.oecd.org/coronavirus/policy-responses/rebuilding-tourism-for-the-future-covid-1

9-policy-responses-and-recovery-bced9859/ [accessed 20 January 2021].

Ratten, V., 2019. Tourism entrepreneurship research: a perspective article.Tourism online, 75(1), pp. 122-125. https://doi.org/10.1108/TR-06-2019-0204.

Santarelli, E. \& Vivarelli, M., 2007. Entrepreneurship and the process of firms' entry, survival and growth. Industrial and Corporate Change, 16 (3), pp. 455-488. https://doi.org/10.1093/icc/dtm010.

Shane, S. \& Venkataraman, S., 2000. The Promise of Entrepreneurship as a Field of Research. The Academy of Management Review, 25 (1), pp. 217-226. https://doi.org/10.2307/259271.

Silberberg, T., 1995. Cultural Tourism and Business Opportunities for Museum and Heritage Sites. Tourism Management, $16 \quad$ (5), pp. 361-365. https://doi.org/10.1016/0261-5177(95)00039-Q.

Solvoll, S., Alsos, G. \& Bulanova, O., 2015. Tourism entrepreneurship-review and future directions. Scandinavian Journal of Hospitality and Tourism, 15 (sup.1), pp. 120-137. https://doi.org/10.1080/15022250.2015.1065592.

Sternberg, R., 2011. Regional determinants of entrepreneurial activities - theories and empirical design. In: M. Fritsch, ed. Handbook of research on entrepreneurship and regional 
development. National and regional perspectives. Cheltenham, UK: Edward Elgar, pp. 33-57. https://doi.org/10.4337/9780857936493.00007.

Sundbo, J., Orfila-Sintes, F. \& Sørensen, F., 2007. The innovative behaviour of tourism firms-comparative studies of Denmark and Spain. Research Policy, 36 (1), pp. 88-106. https://doi.org/10.1016/i.respol.2006.08.004.

The World Tourism Organization (UNWTO), 2018. Tourism Highlights. 2019 Edition, Madrid, Spain: UNWTO.

Thelwall, M., 2008. Bibliometrics to webometrics. Journal of Information Science, 34 (4), pp. 605-621. https://doi.org/10.1177/0165551507087238.

Thomas, S., Shaw, G. \& Page, S., 2011. Understanding small firms in tourism: A perspective on research trends and challenges. Tourism Management, 32 (5), pp. 963-976. https://doi.org/10.1016/i.tourman.2011.02.003.

UNWTO, 2013. Economic Crisis, International Tourism Decline and its Impact on the Poor, Madrid, Spain: World Tourism Organization.

Zupic, I. \& Čater, T., 2015. Bibliometric methods in management and organization. Organzational Research Methods, 18, pp. 429-472. https://doi.org/10.1177/1094428114562629.

\section{Bio-note}

Carmen Florina Fagadar graduated at Emanuel University of Oradea, Faculty of Management. She is currently a Ph.D. student at University of Oradea. Her doctoral research is focused on entrepreneurship education in the age of digitalization and globalisation.

Diana Teodora Trip graduated at 'Babes-Bolyai' University of Cluj-Napoca, Faculty of Economic Sciences and Business Administration. She is currently a Ph.D. student at University of Oradea. Her doctoral research is focused on entrepreneurship and innovation in Romanian tourism.

Daniel Badulescu graduated at Bucharest University of Economics and currently is Professor and Ph.D. supervisor at the Doctoral School in Economics within the University of Oradea, Romania. 